\title{
PERANCANGAN SISTEM INFORMASI SIMPAN PINJAM DI KOPERASI KARYAWAN MT HARYONO BEBASIS JAVA
}

\author{
Meli Agustina ${ }^{1}$, Nofita Rismawati ${ }^{2}$ Acep $^{3}$ \\ Program Studi Informatika, Fakultas Teknik dan Ilmu Komputer, Universitas Indraprasta PGRI \\ Jalan Raya Tengah No 80, Kelurahan Gedong, Pasar Rebo, Jakarta Timur \\ Magstna18@gmail.com¹, novi.9001@gmail.com², acepdpk@gmail.com ${ }^{3}$
}

\begin{abstract}
Abstrak
Penelitian ini bertujuan untuk membuat suatu aplikasi simpan pinjam koperasi karyawan, serta mendeskripsikan hasil uji coba sistem aplikasi. Metode penelitian yang digunakan adalah metode Grounded Research. Peneliti mengumpulkan data dan observasi di koperasi karyawan Indomobil dengan metode wawancara langsung kepada penanggung jawab dan petugas koperasi. Peneliti menemukan berbagai masalah yang dihadapi di koperasi tersebut yaitu kendala sistem yang masih sangat manual sehingga pekerjaan tidak efekti dan efisien. Hasil penelitian dapat disimpulkan dengan adanya aplikasi yang sudah terkomputerisasi, transaksi di koperasi semakin mudah dan cepat.
\end{abstract}

Kata Kunci: Sistem Informasi, Simpan Pinjam, Koperasi

\begin{abstract}
This research aims to create an application for employee cooperative borrowing, as well as describing the test results of application systems. The research method used is the Grounded Research method. Researchers gather data and observations at IndoMobil employee cooperative with direct interview methods and cooperative officers. Researchers found various problems encountered in the cooperative, namely system constraints that are still very manual so that the work is not effective and efficient. Research results can be concluded by the application that has been computerized, transactions in cooperatives will be easier and faster.
\end{abstract}

Keywords: Information Systems, Savings and Loans, Cooperatives

\section{PENDAHULUAN}

Penggunaan sarana komputer dalam semua aspek kehidupan saat ini sudah tidak asing lagi. Komputer tidak hanya digunakan dalam bidang ilmu pengetahuan saja tetapi digunakan juga dalam berbagai bidang dan disiplin ilmu, terutama pada teknologi informasi yang sangat menunjang efektifitas serta efisiensi kerja dalam memenuhi perkembangan perekenomian serta membantu kebutuhan akan kecepatan mengolah data. Di dalam koperasi dibutuhkan kecepatan dalam mengolah data serta prosedur yang tersusun dengan baik, perhitungan bunga yang tepat serta daftar keuangan yang terdata secara keseluruhan dengan baik, namun terkadang terdapat masalah dalam penanganannya, salah satu masalah yang cukup kompleks adalah tatanan administrasi pencatatan simpan pinjam dan juga legalitas aplikasi yang digunakan. Maka peneliti ingin membuat perancangan sistem informasi yang baik untuk koperasi. Perancangan adalah proses pengembangan spesifikasi baru berdasarkan rekomendasi hasil analisa sistem.(Sutabri, 2012)

Objek penelitian yang di ambil oleh peneliti adalah salah satu koperasi di MT Haryono Jakarta yang masih memiliki kendala-kendala dalam mengelola simpan pinjam dikarenakan belum memiliki sistem, berdasarkan kondisi-kondisi tersebut seperti prosedur peminjaman dan pengembalian dana, perhitungan bunga membutuhkan waktu yang lama, selain itu dapat terjadi hilangnya catatan anggota koperasi akibat keteledoran petugas koperasi, salah satu petugas koperasi, salah menghitung jumlah jumlah bunga yang harus dibayar dan kurang efisiennya para peminjam dana terhutang di koperasi tersebut serta tidak adanya aplikasi yang saat ini sering kita ketahui banyak yang tidak legal. Sehingga untuk mengatasi masalah tersebut, dibutuhkan sistem informasi koperasi berbasis komputerisasi dengan sumber daya bebas. Sistem disini dapat diartikan sebagai kumpulan atau himpunan dari unsur, komponen, atau variable yang terorganisasi, saling berinteraksi, saling tergantung satu sama lain dan terpadu.(Subhan, 2012) 
Berdasarkan kondisi-kondisi tersebut maka dengan ini peneliti ingin membuat sebuah program aplikasi berbasis komputer menggunakan aplikasi Java untuk menggantikan sistem manual yang ada. Java adalah Bahasa pemograman yang dapat dijalankan di berbagai jenis komputer dan berbagai jenis sistem operasi termasuk telepon genggam. Java dikembangkan oleh Sun Microsystem dan dirilis tahun 1995. Java merupakan suatu teknoogi perangkat lunak yang digolongkan multi platform. Selain itu, Java juga merupakan satu platform yang memiliki virtual machine dan library yang diperlukan untuk menulis dan menjalankan suatu program.(Wahana, 2015) Dengan menggunakan database MySQL. MySQL merupakan sebuah program database server yang mampu menerima dan mengirimkan datanya dengan sangat cepat, multi user serta menggunakan perintah standar SQL (Stuctured Query Language). (Nugroho, 2014) Dan menggunakan aplikasi pendukung agar aplikasi dapat berjalan dengan sempurna yaitu aplikasi Xampp. XAMPP adalah perangkat lunak (free Software) bebas, yang banyak mendukung sistem informasi, yang merupapakan kompilasi dari beberapa program. Fungsi XAMPP sendiri adalahsebagai server yang berdiri sendiri (localhost), yang terdiri dari beberapa program antara lain: Apache HTTP Server, MySQL database, dan penerjemah bahasa yang ditulis dengan bahasa pemrograman PHP dan Perl. Program ini tersedian dalam GNU General Public License dan bebas, merupakan web server yang mudah untuk digunakan yang dapat menampilkan halaman web yang dinamis.(MADCOMS, 2016) Karena sistem berbasis komputer menggunakan aplikasi java dapat meningkatkan efisiensi dan kefektifan kerja, memudahkan dalam pencatatan data anggota koperasi, peminjaman dan pengembaliaan dana, agar data mengenai dana dapat terjamin keamanannya.

Tujuan Penelitian ini adalah untuk mengetahui sistem informasi simpan pinjam yang sedang berjalan di Koperasi Indomobil Karyawan MT Haryono. Selain itu untuk membuat perancangan sistem informasi simpan pinjam yang dapat mengatasi masalah sistem yang lama di Koperasi Karyawan Indomobil MT Haryono. Dan juga untuk menguji dan menerapkan perancangan sistem informasi simpan pinjam yang di buat dengan bahasa pemrogramman Java sehingga dihasilkan program aplikasi yang dapat menyimpan dan memproses transaksi simpan pinjam di Koperasi Karyawan Indomobil MT Haryono.

Manfaat yang diharapkan akan diperoleh dari penelitian ini adalah untuk mengasah kemampuan peneliti yang sangat terbatas dalam merancang suatu program, meningkatkan pengetahuan tentang sistem informasi dan dapat dijadikan sebagai sarana pengenalan atau tambahan informasi serta referensi bagi masyarakat dan peneliti lain yang membutuhkan.

\section{PENELITIAN RELEVAN}

Penelitian relevan merupakan penelitian terdahulu atau sebelumnya yang relevan dengan konsep penelitian sehingga menjadi acuan atau dasar mengembangkan suatu hasil penelitian sebelumnya. Berikut peneliti mengambil sumber dari beberapa jurnal, yang pertama adalah jurnal dari Pratiwi, Asti Herliana dari Universitas Kebangsaan Bandung, Program Studi Teknik Informatika, dengan Nomor ISSN 2335-6579, pada tahun 2015 yang berjudul "Analisis dan Desain Sistem Informasi Simpan Pinjam pada Koperasi Sejahtera Bersama Bandung" penelitian jurnal meliputi sistem koperasi simpan pinjam yang selama ini transaksi yang dilakukan masih dikombinasikan dengan proses manual untuk proses peminjamannya, hal tersebut memakan waktu lama untuk proses transaksinya. Dilaksanakan penelitian bertujuan untuk memberikan kemudahan untuk karyawan dalam mengelola laporan sehingga lebih akurat dan efisien.(Pratiwi \& Herliana, 2016) Yang kedua yaitu jurnal dari Joni Karman dari STMIK MUSIRAWAS Jambi, Program Studi Sistem Informasi, dengan Nomor ISSN 2404 - 1730, pada tahun 2018 yang berjudul "Sistem Informasi Simpan Pinjam Koperasi pada MTS Negeri Kota Lubuklinggau" dalam penelitian jurnal ini sistem masih menggunakan buku dalam pencatatan data anggota, data daftar simpanan, pinjaman, angsuran serta laporan masih membutuhkan waktu yang lama, kemudian petugas koperasi melakukan pencatatan kembali data-data setiap transaksi dengan menggunakan excel. Maka peneliti berasumsi diperlukannya sistem komputer yang dirancang secara khusus agar memudahkan dalam semua transaksi di koperasi MTS Negeri Kota Lubuklinggau.(Karman \& Martadinata, 2017) 


\section{METODE PENELITIAN}

Metode penelitian yang digunakan peneliti adalah metode grounded (Grounded Reaserch) yaitu suatu metode penelitian berdasarkan pada fakta dan menggunakan analisa perbandingan dengan tujuan mengadakan generalisasi empiris, menetapkan konsep, membuktikan teori, mengembangkan teori, pengumpulan dan analisa data dalam waktu yang bersamaan. Dalam penelitian ini data merupakan sumber teori atau teori berdasarkan data. Mengolah dan menganalisa data membangun hipotesis menjadi teori serta menulis draft laporannya dari waktu ke waktu. Setelah melakukan pengumpulan data peneliti melanjutkan proses penelitian sesuai dengan langkah-langkah pokok yang digunakan pada metode ini, yaitu menentukan masalah yang ingin diselidiki, mengumpulkan masalah yang ditemukan serta membuat laporan hasil penelitian.

\section{a. Teknik Observasi}

Metode penelitian data pada penelitian ini menggunakan observasi non partisipan, yaitu metode pengumpulan data yang dilakukan dengan cara mengadakan pengamatan langsung ke Koperasi Karyawan Indomobil MT Haryono guna memperoleh gambaran yang tepat mengenai masalah dan hambatan yang ada serta upaya yang diperlukan. Pengamatan ini dilakukan secara langsung merupakan cara ampuh untuk menguji suatu kebenaran. Peneliti bukan hanya mencari dan mengumpulkan data, tetapi juga langsung melakukan klasifikasi terhadap data tersebut.

\section{b. Studi Pustaka}

Teknik ini digunakan untuk memperoleh dasar-dasar dan pendapat secara tertulis yang dilakukan dengan cara mempelajari berbagai literature yang berhubungan dengan masalah yang teliti. Hal ini juga dilakukan untuk mendapatkan data primer yang akan digunakan sebagai landasan perbandingan antara teori dengan prakteknya di lapangan.

\section{c. Studi Lapangan}

Metode pengumpulan data yang digunakan dalam penelitian ini adalah teknik wawancara kepada penanggung jawab koperasi yang beralamat di Wisma Indomobil Jl. Letjen M.T Haryono Kav. 8, Jakarta 13330 yang bertanggung jawab dan terlibat langsung dalam sistem simpan pinjam pada Koperasi Karyawan Indomobil MT Haryono. Dari hasil wawancara didapati, sistem yang berjalan di Koperasi Karyawan Indomobil masih berupa Microsoft Office untuk pendataan data anggota, simpanan, pinjaman dan angsuran. Untuk semua laporan masih menggunakan buku besar jurnal sehingga dapat beresiko hilangnya data-data anggota, simpanan, pinjaman dan angsuran ketika suatu saat dibutuhkan. Untuk proses peminjaman dan pengembalian dana di Koperasi Karyawan Indomobil masih memerlukan waktu yang cukup lama sehingga ini dapat memperlambat jalannya transaksi di koperasi tersebut. Maka peneliti berharap dengan adanya sistem ini maka karyawan koperasi tersebut dapat dengan mudah melakukan transaksi simpan pinjam di Koperasi Karyawan Indomobil.

\section{d. Analisis Perancangan}

1. Analisis Kebutuhan Sistem, Dalam tahapan perancangan sistem informasi sangat perlu menggunakan analisa kebutuhan, dapat berguna untuk memperoleh data-data yang akan digunakan sebagai inputan sistem informasi dari pengolahan data koperasi simpan pinjam.

2. Perancangan sistem informasi merupakan pengembangan sistem baru dari sistem lama yang telah ada, dimana masalah-masalah yang ada pada sistem yang lama diharapkan dapat teratasi pada sistem yang baru dan dapat diimplementasikan dengan kebutuhan pengguna.

3. Desain Aplikasi, pada tahap ini akan dilakukan perancangan struktur data, karakteristik antarmuka, dan tampilan layar dari sistem yang akan dirancang agar menarik dan juga menghibur.

4. Pengkodean dan pengujian sistem, Sebelum sistem dijalankan maka harus melaksanakan pembuatan "Perancangan Sistem Informasi Simpan Pinjam pada Koperasi Karyawan Indomobil MT Haryono Berbasis Java" dengan perintah kode program. Setelah proses pengkodean selesai maka akan dilakukan proses pengujian terhadap program yang dirancang untuk mengetahui apakah program sudah berjalan dengan benar dan baik sesuai dengan desain yang dilakukan sebelumnya. 
5. Implementasi dan evaluasi, implementasi dilakukan untuk memsatikan apakah semua sistem berjalan dengan baik, dan apakah ada kesalahan pada sistem. Implementasi atau pengujian amat sangat penting dilakukan untuk menjadi peninjau akhir terhadap spesifikasi, desain serta pengkodean. Proses evaluasi dilakukan melalui testing aplikasi untuk mengecek jika terdapat error yang bisa menghentikan program secara tiba-tiba ataupun terdapat fungsifungsi yang tidak berjalan sesuia dengan apa yang telah ditentukan.

6. Tahap Penulisan laporan. tahap ini dilakukan pengolahan, analisa, dan pembahasan hasil penelitian serta kesimpulan dari hasil penelitian yang telah dilakukan selama masa penelitian.

\section{HASIL DAN PEMBAHASAN}

Proses Bisnis yang berjalan pada Koperasi Karyawan Indomobil untuk simpan pinjam adalah sebagai berikut :

1. Anggota secara langsung memberikan data anggota admin koperasi dengan memberikan datadata pribadi. Admin menerima data anggota atau data-data pribadi. Setelah menerima data anggota kemudian admin akan memberikan id dan kartu anggota.

2. Anggota memberikan simpanan kepada koperasi yang akan diterima oleh petugas koperasi. Setelah menerima simpanan kemudian petugas koperasi bukti pembayaran kepada anggota.

3. Anggota melakukan pengajuan pinjaman kepada petugas koperasi. Setelah ajuan diterima maka anggota dapat meminjam uang sesuai yang diajukannya. Setelah itu anggota menerima bukti pembayaran dari petugas koperasi.

4. Anggota melakukan pengangsuran pinjaman setiap bulannya kepada petugas koperasi. Setelah melakukan pembayaran angsuran anggota koperasi menerima bukti pembayaran angsuran dari petugas koperasi.

5. Pada setiap bulannya akan dibuatkan laporan data anggota, simpanan wajib, peminjaman uang dan angsuran pinjaman. Data-data tersebut bertujuan untuk diketahui oleh pemimpin koperasi. Data-data pinjaman dan angsuran akan dibuatkan rekap daa setiap akhir bulan untuk diketahui juga oleh pemimpin koperasi.

Analisis permasalahan yang dapat disimpulkan dari hasil yang di lakukan di Koperasi Karyawan Indomobil MT Haryono bahwa, perusahaan ini termasuk salah satu perusahaan yang belum memiliki sistem informasi simpan pinjam berbasis komputerisasi, sehingga dirasakan masih sangat membutuhkan sistem yang mampu dan memberikan kemudahan bagi bagian-bagian yang terkait dalam sistem pengolahan data koperasi. Ada beberapa permasalahan yang dimiliki oleh pihak perusahaan antara lain, laporan data simpan pinjam anggota koperasi masih dilakukan pencatatan manual dengan menggunakan catatan sehingga menyulitkan petugas koperasi ketika akan melakukan pencarian data maupun pengarsipan data. Pencatatan simpan pinjam yang berjalan belum maksimal karena penggunaan berkas sebagai sarana pencatatan anggota. Dalam proses pengarsipan simpan pinjam koperasi masih menggunakan pencatatan buku besar sehingga petugas koperasi sering kesulitan mencari data-data simpan pinjam anggota.

Alternatif penyelesaian masalah yang peneliti usulkan dengan membuat sebuah aplikasi sistem informasi simpan pinjam dengan menggunakan bahasa pemrogramman java dan penyimpanan data-data pada media database. Dengan adanya aplikasi ini diharapkan mampu memberikan kontribusi yang positif bagi kemajuan dalam pengolahan data-data simpan pinjam koperasi. Proses pencarian data tidak lagi membutuhkan waktu yang lama karena data-data yang sudah tersimpan pada media database. Dengan usulan ini diharapkan pemasalah pada pengolahan data-data simpan pinjam koperasi dapat tertangani dengan cepat dan akurat

Berikut ini adalah Gambaran sistem yang diusulkan di Koperasi Karyawan Indomobil MT Haryono secara keseluruhan dalam diagram konteks dan ERD (Entity Relationship Diagram). 


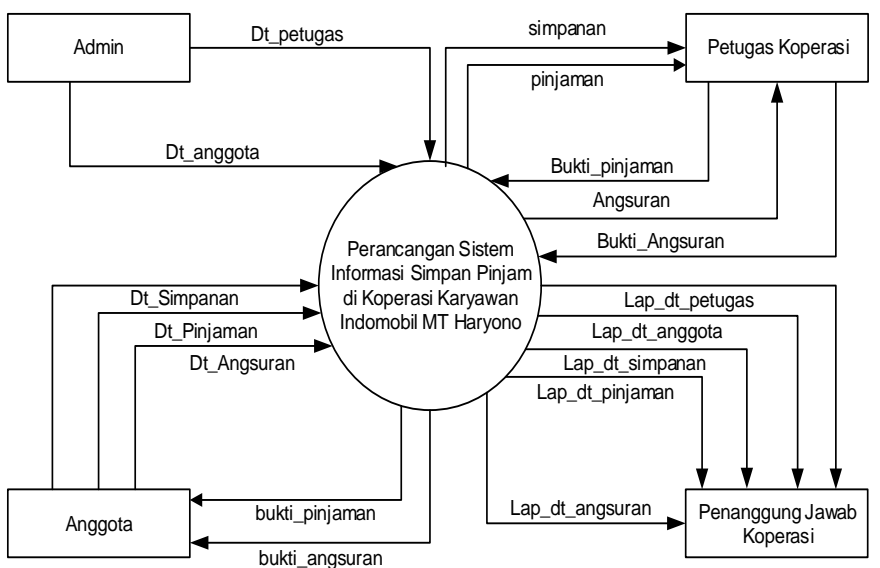

Gambar 1. Diagram Konteks

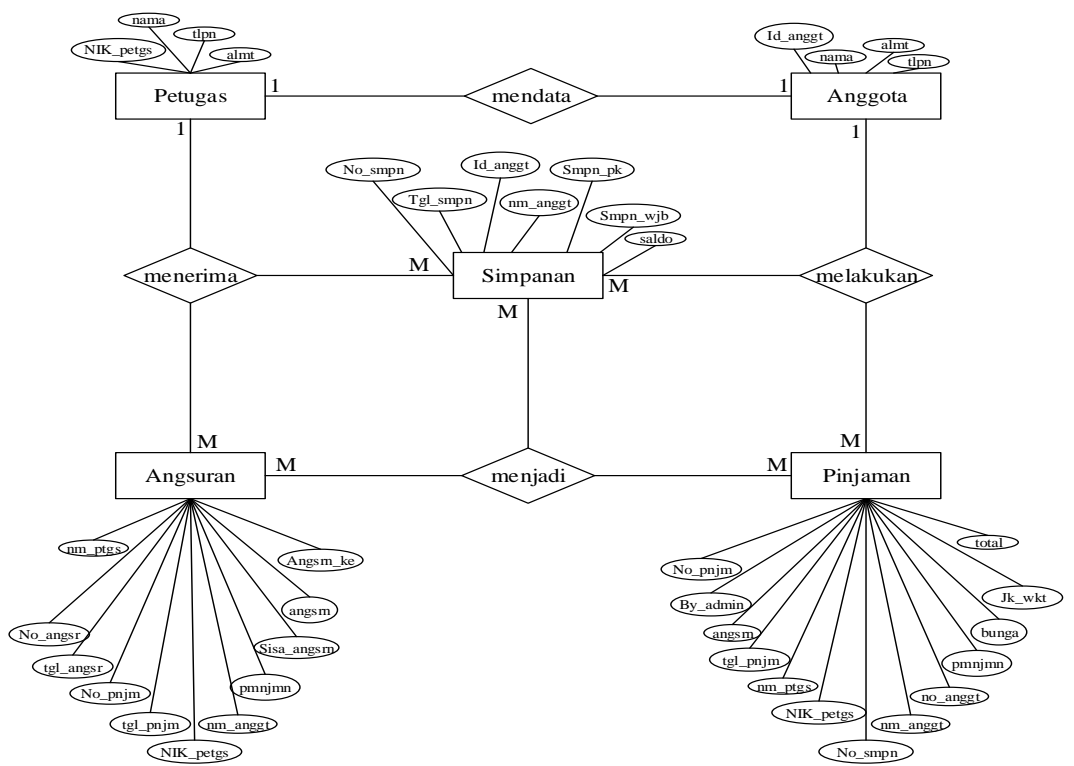

Gambar 2. Entity Relationship Diagram (ERD)

Proses selanjutnya peneliti membuat aplikasi ini dengan menggunakan java netbeans edisi 8.2 berbasis desktop dan menggunakan basisdata $M y S Q L$.

Dibawah ini adalah tampilan layar dari aplikasi Simpan Pinjam di Koperasi Karyawan Indomobil MT Haryono.

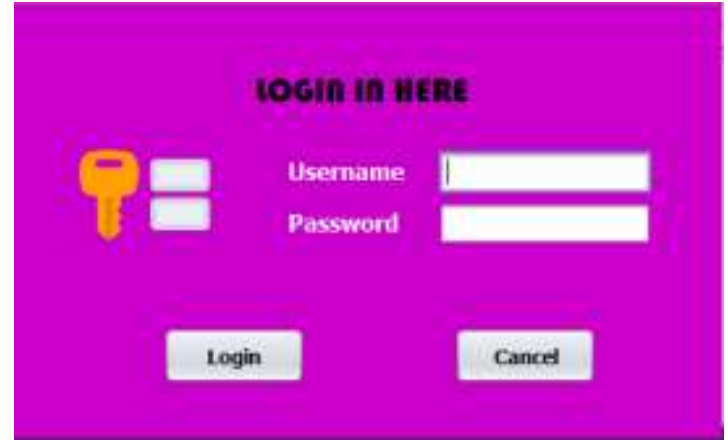

Gambar 3. Tampilan layar login

Tampilan form login ini muncul di pengolahan data aplikasi simpan pinjam pada Koperasi Karyawan Indomobil untuk diisi oleh admin sebagai user. Masukan username dan password yang 
sesuai dengan hak akses supaya bisa mengoperasikan aplikasi simpan pinjam. Jika username dan password sesuai, maka akan masuk kepada tampilan menu utama.

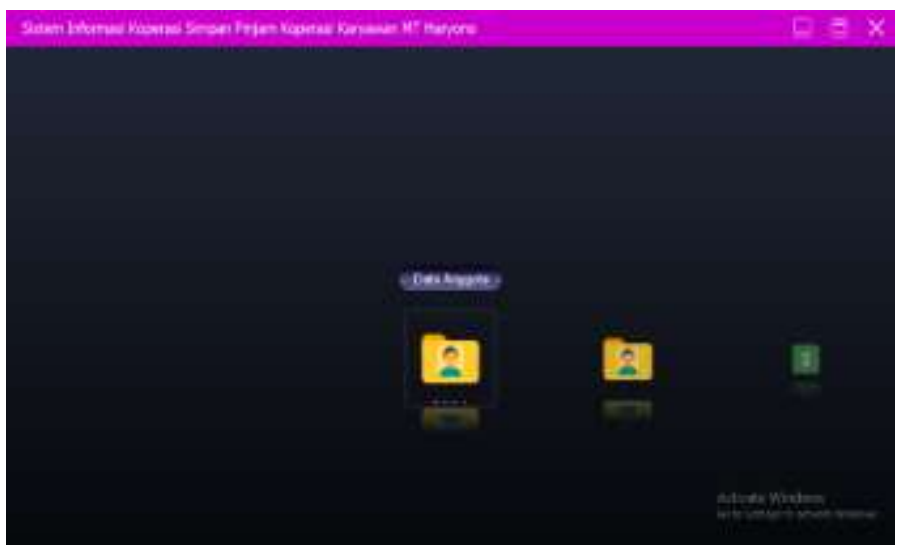

Gambar 4. Tampilan Layar Menu Utama

Tampilan menu utama ini terdapat beberapa icon menu yang akan menampilkan form-form transaksi diantaranya adalah data utama, master data dan laporan.

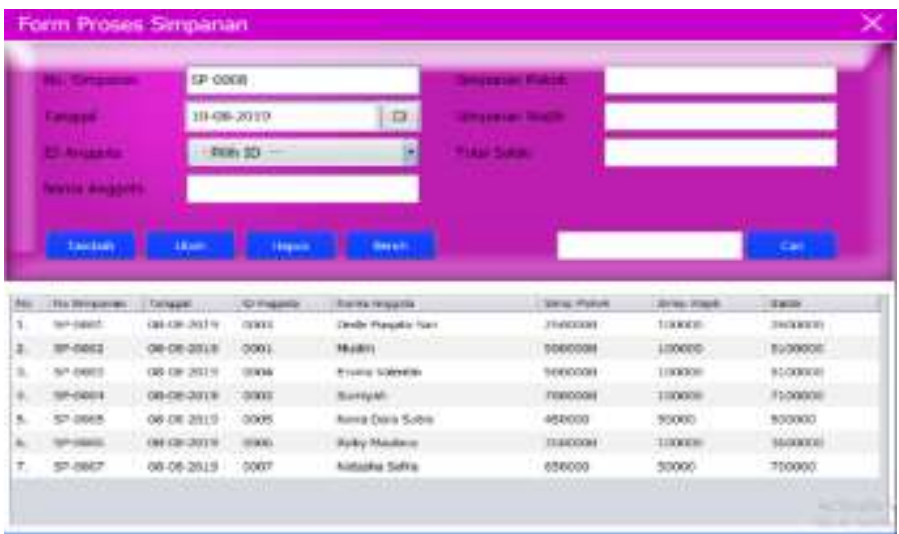

Gambar 5. Tampilan Form Simpanan

Tampilan form simpanan ini, user dapat melakukan penambahan data simpanan, mengubah dan menghapus data simpanan. Masukan No Simpanan untuk melakukan pengecekan data-data yang sudah tersimpan. Lakukan pengisian apabila akan dilakukan penambahan data dan tekan tombol (tambah) untuk menyimpan data, untuk memperbarui data tombol (ubah), dan untuk menghapus data klik tombol (hapus). Pilih tombol (bersih) apabila ingin membersih data yang ada di tiap kolom. Pilih tombol (cari) untuk mencari data yang dibutuhkan.

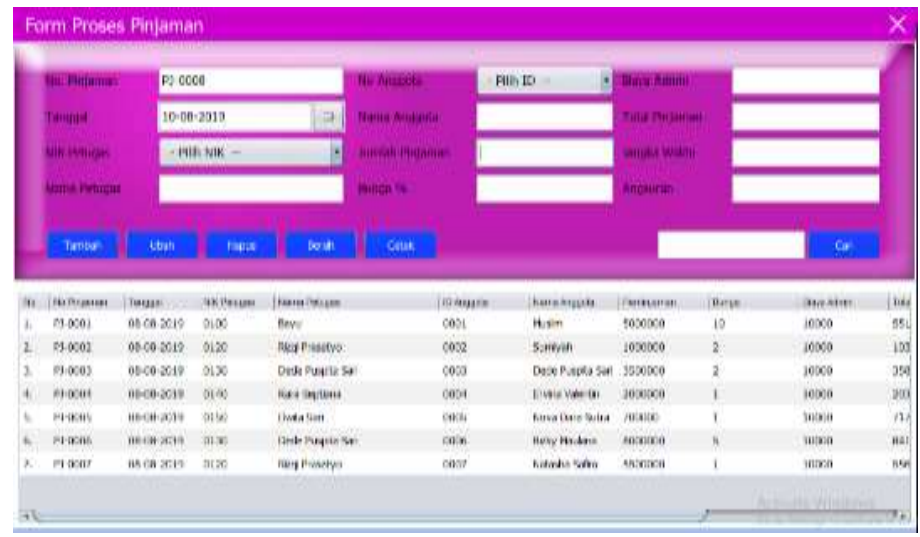

Gambar 6. Tampilan Form Pinjaman 
Tampilan form pinjaman ini, user dapat melakukan penambahan data pinjaman, mengubah dan menghapus data pinjaman. Masukan No Pinjaman untuk melakukan pengecekan data-data yang sudah tersimpan. Lakukan pengisian apabila akan dilakukan penambahan data dan tekan tombol (tambah) untuk menyimpan data, untuk memperbarui data tombol (ubah), dan untuk menghapus data klik tombol (hapus). Pilih tombol (bersih) apabila ingin membersih data yang ada di tiap kolom. Pilih tombol (cari) untuk mencari data yang dibutuhkan

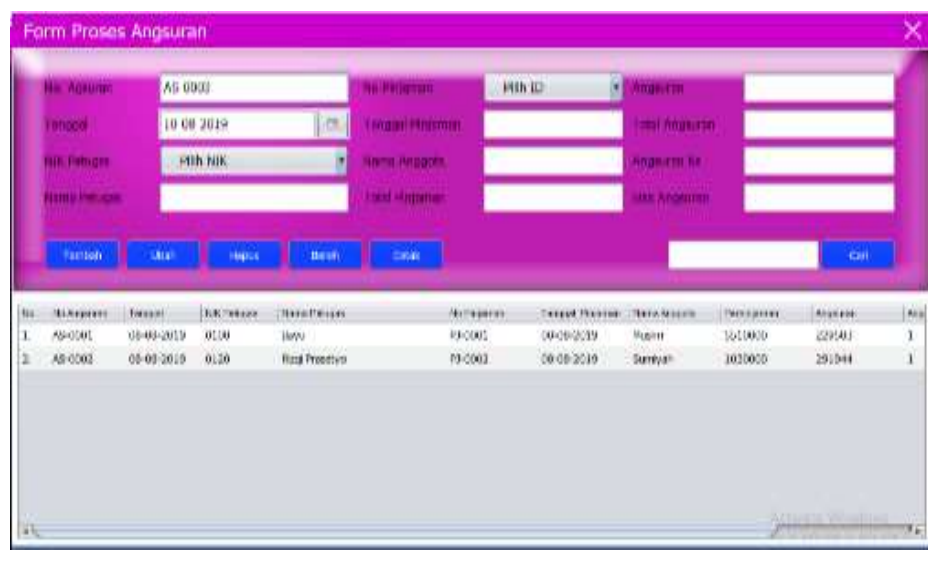

Gambar 7. Tampilan Form Angsuran

Tampilan form angsuran ini, user dapat melakukan penambahan data angsuran, mengubah dan menghapus data simpanan. Masukan No Angsuran untuk melakukan pengecekan data-data yang sudah tersimpan. Lakukan pengisian apabila akan dilakukan penambahan data dan tekan tombol (tambah) untuk menyimpan data, untuk memperbarui data tombol (ubah), dan untuk menghapus data klik tombol (hapus). Pilih tombol (bersih) apabila ingin membersih data yang ada di tiap kolom. Pilih tombol (cari) untuk mencari data yang dibutuhkan.

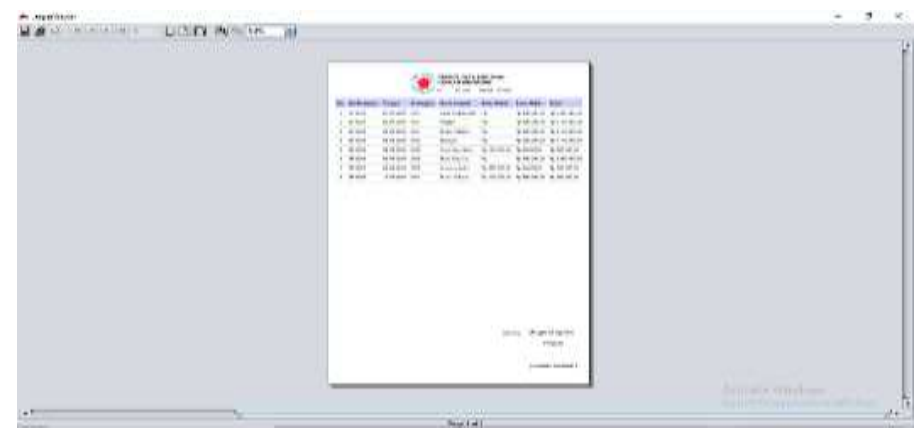

Gambar 8. Tampilan Layar Laporan Simpanan

Tampilan laporan data simpanan ini berisi data-data yang ada pada tabel simpanan. Laporan ini muncul ketika user mengklik tombol laporan data pinjaman pada tampilan menu utama.

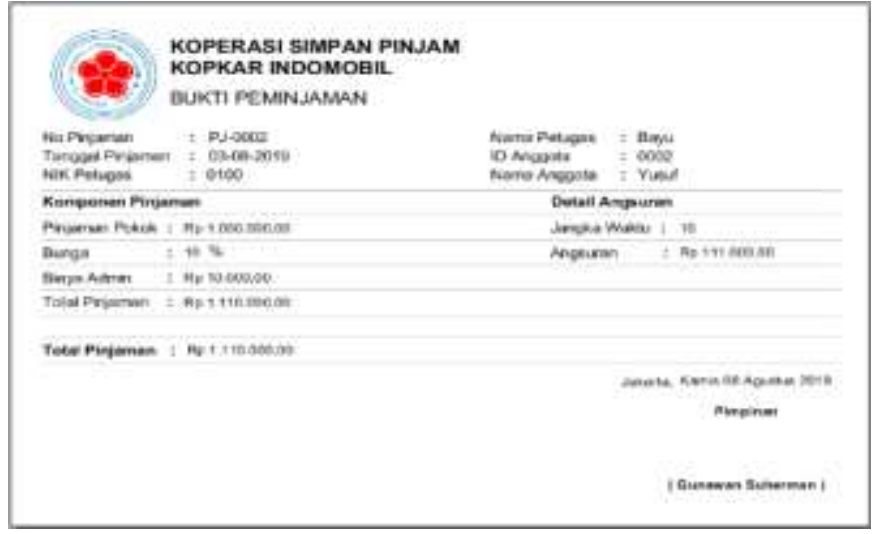

Gambar 9. Tampilan Layar Bukti Peminjaman 
Tampilan bukti peminjaman ini berisi data-data yang ada pada proses pinjaman. Bukti ini muncul ketika user mengklik tombol cetak pada pada proses pinjaman. User bisa mencetak bukti ini dengan mengklik tombol yang berlogo printer yang ada di bagian header kiri atas.

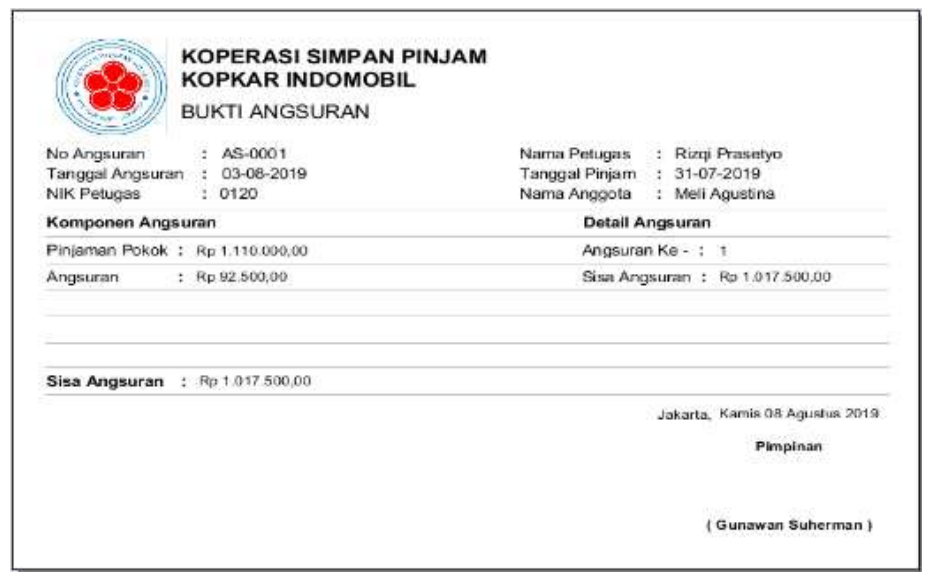

Gambar 10. Tampilan Layar Bukti Angsuran

Tampilan bukti angsuran ini berisi data-data yang ada pada proses pinjaman. Bukti ini muncul ketika user mengklik tombol cetak pada pada proses pinjaman. User bisa mencetak bukti ini dengan mengklik tombol yang berlogo printer yang ada di bagian header kiri atas.

\section{SIMPULAN}

Berdasarkan pembahasan dari penelitian ini , maka peneliti dapat mengambil kesimpulan yaitu aplikasi ini dapat memberikan fasilitas untuk memudahkan transaksi simpan pinjam yang ada di Koperasi Karyawan Indomobil, sehingga dapat memberikan data-data secara cepat dan akurat., Aplikasi ini mencangkup beberapa data, yaitu data-data petugas Koperasi Indomobil, data-data anggota Koperassi Indomobil, data simpanan wajib dan simpanan pokok, data-data peminjaman yang dilakukan oleh anggota koperasi dan data-data angsuran peminjam, Aplikasi ini dapat menghasilkan output laporan yang dibutuhkan oleh penanggung jawab koperasi secara cepat dan akurat. Laporan laporan tersebut berupa laporan petugas, laporan anggota, laporan simpanan, laporan pinjaman dan laporan angsuran.

\section{DAFTAR PUSTAKA}

Karman, J., \& Martadinata, A. T. (2017). Sistem Informasi Geografis Lokasi Pemetaan Masjid Berbasis Android Pada Kota Lubuklinggau. Stmik Musirawas.

MADCOMS. (2016). PEMROGRAMAN PHP dan MySQL untuk pemula. In ANDI.

Nugroho, B. (2014). Dasar Pemrograman Web PHP-MySQL dengan Dreamweaver. Gava Media. https://doi.org/10.1016/0378-1119(87)90155-7

Pratiwi, P., \& Herliana, A. (2016). ANALISIS DAN DESAIN SISTEM INFORMASI SIMPAN PINJAM PADA KOPERASI SEJAHTERA BERSAMA BANDUNG. Jurnal Informatika. https://doi.org/10.31311/ji.v2i1.71

Subhan, M. (2012). Analisa PErancangan Sistem. In Analisa perancangan sistem.

Sutabri, T. (2012). Analisis Sistem Informasi. In Analisa Sistem Informasi.

Wahana, K. (2015). Membangun Sistem Informasi Java dengan NetBeans dan MySQL. Andi Ofset. 